\title{
Occurrence of protozoans \& their limnological relationships in some ponds of Mathbaria, Bangladesh
}

Pronob Kumar Mozumder ${ }^{1 *}$, Marjia Akhter Banu ${ }^{1}$, M. Niamul Naser ${ }^{1}$, Md. Shahadat Ali $^{1}$, Munirul Alam $^{2}$, R. Bradley Sack ${ }^{3}$, Rita R. Colwell ${ }^{4}$ \& Anwar Huq

${ }^{1}$ Department of Zoology, University of Dhaka, Bangladesh ; ${ }^{2}$ Enteric \& Food Microbiology Laboratory, ICDDR, B.

Dhaka; ${ }^{3}$ Johns Hopkins Bloomberg School of Public Health, Baltimore, Maryland, USA ; ${ }^{4}$ Center for Bioinformatics \& Computational Biology, University of Maryland, College Park, USA ; ${ }^{5}$ Maryland Pathogen Research Institute, University of Maryland, USA.

*Corresponding author E-mail: pronob22du@yahoo.com

\section{Sample collection and identification of protozoans}

Water samples were collected fortnightly between October 2004 to May 2005 from four water bodies of Mathbaria of Pirojpur district in Bangladesh. For zooplankton sample collection, 100 liters of water were filtered successively through $20 \mu \mathrm{m}$ mesh nylon nets (Millipore corp., Bedford, MA), and 50 $\mathrm{ml}$ of the concentrates were collected initially as a crude measure of zooplankton. From $50 \mathrm{ml}$ concentrates, $10 \mathrm{ml}$ was used for analysis and the samples were immediately preserved in 5\% buffered formaldehyde solution. The bottle containing the zooplankton was gently swiveled (clock wise) for equal suspension of zooplankton in the sampled water. By using a clean large mouth $10 \mathrm{ml}$ pipette, $1 \mu \mathrm{l}$ of suspended material was placed in counting cell slot. The counting cell was then covered with a glass slide and examined under a compound binocular microscope at a magnificent of $40 \times$ to $100 \mathrm{X}$. The Protozoan samples were observed under a compound microscope (Axioskop 40, Japan). For protozoans analysis, heliber bacteria single round cell (Cat no. Z 30000 LOT 11756) was used. The specimens were identified up to genera level. Quantitative analysis was followed by the total count method of Welch (1948). Identification was made following Ward \& Whipple (1959), Tonapi
(1960), Mellanby (1975), Bhouyain \& Asmat (1992), \& Ali \& Chakrabarty (1992).

\section{Protozoans composition}

In this study 3 genera of the protozoans were identified from four ponds of Mathbaria. From the accumulated data in the total study period abundance of protozoans per sampling (per week) varied from 15 individuals/l in March'2005 to 196 individuals/l in October'2004 with an average of 93 individuals/l. (Table 1).

Variations in the percentage composition of average protozoans during the study period were, $1.91 \%$ in Kachisira pond, $55.5 \%$ in South Mithakhali pond, $10.53 \%$ in Mathbaria Bazar pond and $32.06 \%$ in BRAC pond (Table 2).

Variations in total protozoans during the study period were 114 ind./I in Kachisira pond, 3305 ind./I in South Mithakhali pond, 627 ind./I in Mathbaria Bazar pond and 1909 ind./I in BRAC pond (Fig.1,Table 2).

From this study of four ponds in Mathbaria Holophrya sp. was $0.96 \%$, Glaucoma sp. $74.16 \%$, Nassula sp. $12.44 \%$ and unidentified protozoans were $12.44 \%$ of total protozoans in total study period (Table 2, Fig.2). 
Table 1. Pond wise variations in the abundance (Individual/l) of protozoan fauna in Mathbaria during the period of October 2004 to May 2005.

\begin{tabular}{|c|c|c|c|c|c|c|c|c|c|c|c|c|c|c|c|c|c|}
\hline \multirow[t]{4}{*}{ Ponds } & \multicolumn{17}{|c|}{ Months } \\
\hline & \multirow{2}{*}{\multicolumn{2}{|c|}{$\begin{array}{c}\text { Oct. } \\
\text { Weeks }\end{array}$}} & \multirow{2}{*}{\multicolumn{2}{|c|}{$\begin{array}{c}\text { Nov. } \\
\text { Weeks }\end{array}$}} & \multirow{2}{*}{\multicolumn{2}{|c|}{$\begin{array}{c}\text { Dec. } \\
\text { Weeks }\end{array}$}} & \multirow{2}{*}{\multicolumn{2}{|c|}{$\begin{array}{c}\text { Jun. } \\
\text { Weeks }\end{array}$}} & \multirow{2}{*}{\multicolumn{2}{|c|}{$\begin{array}{c}\text { Feb. } \\
\text { Weeks }\end{array}$}} & \multirow{2}{*}{\multicolumn{2}{|c|}{$\begin{array}{c}\text { Mar. } \\
\text { Weeks }\end{array}$}} & \multirow{2}{*}{\multicolumn{2}{|c|}{$\begin{array}{c}\text { Apr. } \\
\text { Weeks }\end{array}$}} & \multicolumn{2}{|c|}{ May. } & \multirow{3}{*}{ Average } \\
\hline & & & & & & & & & & & & & & & & eeks & \\
\hline & $1^{\mathrm{st}}$ & $3^{\text {rd }}$ & $1^{\text {st }}$ & $3^{\text {rd }}$ & $1^{\mathrm{st}}$ & $3^{\text {rd }}$ & $1^{\mathrm{st}}$ & $3^{\text {rd }}$ & $1^{\mathrm{st}}$ & $3^{\text {rd }}$ & $1^{\mathrm{st}}$ & $3^{\text {rd }}$ & $1^{\mathrm{st}}$ & $3^{\text {rd }}$ & $1^{\mathrm{st}}$ & $3^{\text {rd }}$ & \\
\hline Kacl & 0 & 57 & 0 & 0 & 0 & 0 & 0 & 0 & 0 & 0 & 57 & 0 & 0 & 0 & 0 & 0 & 7 \\
\hline & 0 & 741 & 342 & 285 & 114 & 114 & 228 & 342 & 342 & 455 & 285 & 0 & 57 & 0 & 0 & 0 & \\
\hline$M c$ & 0 & 0 & 0 & 114 & 0 & 0 & 242 & 57 & 57 & 0 & 0 & 0 & 0 & 57 & 0 & 0 & \\
\hline BRA & 0 & 0 & 0 & 0 & 57 & 114 & 228 & 57 & 114 & 0 & 57 & 57 & 285 & 542 & 0 & 455 & 123 \\
\hline Average & 0 & 196 & 86 & 100 & 43 & 57 & 175 & 114 & 129 & 114 & 100 & 15 & 85 & 150 & 0 & 114 & 93 \\
\hline
\end{tabular}

Table 2. Percentage composition of different protozoans in four ponds during the study period in Mathbaria.

\begin{tabular}{lcccccccccc}
\hline Ponds & \multicolumn{2}{c}{ Holophrya sp. } & \multicolumn{2}{c}{ Glaucoma sp. } & \multicolumn{2}{c}{ Nassula sp. } & \multicolumn{2}{c}{$\begin{array}{c}\text { Unidentified } \\
\text { protozoans }\end{array}$} & \multicolumn{2}{c}{ Total protozoans } \\
\cline { 2 - 11 } & Individual/I & $\%$ & Individual/I & $\%$ & Individual/I & $\%$ & Individual/l & $\%$ & Individual/l & $\%$ \\
Kachisira pond & 57 & 50 & 0 & 0 & 0 & 0 & 57 & 50 & 114 & 1.91 \\
South Mithakhali pond & 0 & 0 & 2735 & 82.75 & 0 & 0 & 570 & 17.25 & 3305 & 55.50 \\
Mathbaria Bazar pond & 0 & 0 & 57 & 9.09 & 456 & 72.93 & 114 & 18.18 & 627 & 10.53 \\
BRAC pond & 0 & 0 & 1624 & 85.07 & 285 & 14.93 & 0 & 0 & 1909 & 32.06 \\
Total & 57 & 0.96 & 4416 & 74.16 & 741 & 12.44 & 741 & 12.44 & 5955 & 100 \\
\hline Average & 14 & & 1,104 & & 185 & & 185 & 1,489 & \\
\hline
\end{tabular}

\section{Relationship among the different physico- chemical variables and protozoans in the ponds.}

The coefficient of correlation between physicochemical parameters and protozoans of four ponds during the study period were calculated (Table 3) .The relationships are summarized below:

Water temperature showed direct positive relationship with air temperature $(r=0.941)$. Water temperature showed positive relationship with $\mathrm{pH}$ $(r=0.676)$ and $\mathrm{DO}(\mathrm{r}=0.348) . \mathrm{pH}$ showed positive relationship with DO ( $r=0.351)$.

Protozoans showed positive relationship with dissolved oxygen (DO) $(r=0.227)$ while inversely related with water temperature $(r=-0.276)$ and $\mathrm{pH}$ $(r=-0.397)$.

Table 3. Co-efficient of correlations ( $r$ ) between physicochemical variables and protozoans composition of four ponds in Mathbaria during the study period.

\begin{tabular}{ccc}
\hline $\begin{array}{c}\text { Sl. } \\
\text { No. }\end{array}$ & $\begin{array}{c}\text { Co-efficient of } \\
\text { correlations ' } r \text { ' }\end{array}$ \\
\hline 1. & Air temperature and water & 0.941 \\
temperature & \\
2. Water temperature and $\mathrm{pH}$ & 0.676 \\
3. Water temperature and DO & 0.348 \\
4. pH and DO & 0.351 \\
5. Water temperature and & -0.276 \\
protozoans & -0.397 \\
6. pH and protozoans & 0.227 \\
7. DO and protozoans & \\
\hline
\end{tabular}

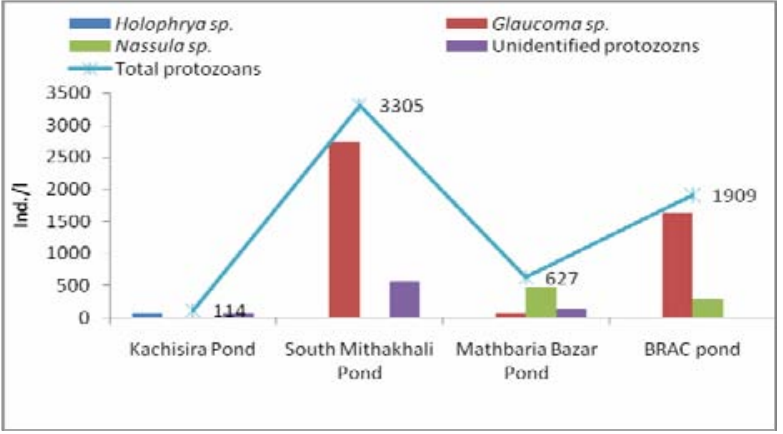

Fig. 1. Occurrence of different protozoan fauna in four ponds during the study period.

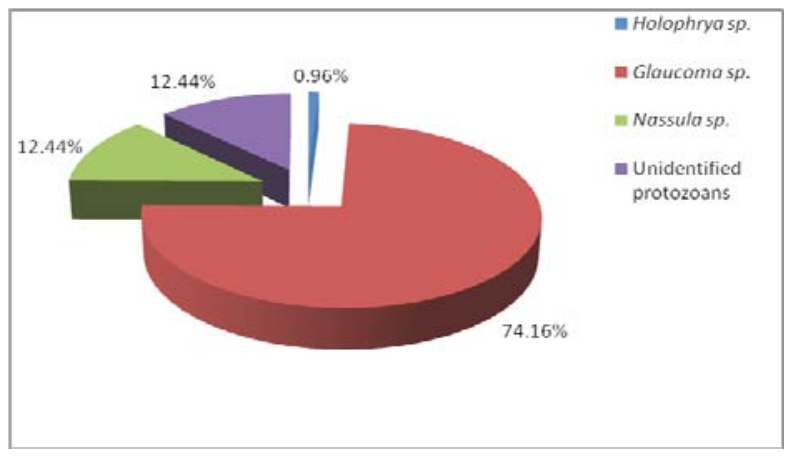

Fig. 2. Showing the average percentage occurrences of different groups of protozoan fauna of four ponds in Mathbaria, during the study period. 


\section{Conclusion}

It is evident from the study that the protozoans showed variation in the selected aquatic environments. The variation depends on the different physicho-chemical variables that exist in the pond ecosystem. However, considering the nature of the ponds, as no fertilizer or nutrients added in the systems, natural productivity of the studied ponds were very high.

\section{Acknowledgements}

The research is an integral part of the major multidisciplinary project entitled 'Epidemiology and Ecology of Vibrio cholerae in Bangladesh' was financed by the National Institute of Health $(\mathrm{NIH})$ research grant \# 1RO1A13912901 under the collaborative agreement between the International Center for Diarrhoeal Disease Research, Bangladesh (ICDDR, B) and Johns Hopkins Bloomberg School of Public Health. The authors gratefully acknowledge the NIH Ecological Surveillance Team at ICDDR, B for supporting this research. The authors are also grateful to Kaji Tamanna Keya, Senior Research Officer, Population Council, Dhaka, for her assistance during the research.

\section{References}

Ali, S. \& Chakrabarty, T. 1992. Bangladesher Mitha Panir Amerudandi Prani (A book of Freshwater Invertebrates of Bangladesh). $1^{\text {st }}$ edition. Bangla Academy, Dhaka, Bangladesh. p. 176.

Bhouyain, A. M. \& Asmat, S.M. 1992. Freshwater Zooplankton from Bangladesh. $1^{\text {st }}$ ed. p.137.

Bhuiyan, A. S., Islam, S. N \& Bhuiyan, S.S. 2008. Seasonal occurrence of some copepods in relation to the physicochemical conditions of a fish pond in Rajshahi, Bangladesh. Fishing Chimes.India 28(4):39-41
Bhuiyan, A. S. \& Nessa, Q. 1988a. A qualitative study of zooplankton in relation to the physicochemical conditions of a fish pond of Rajshahi, Univ. J. Zool. Rajshahi Univ. 17:29-31.

Bhuiyan, A. S. \& Nessa, Q. 1988b. Seasonal variation in the occurrence of some zooplankton in a fish pond. Bangladesh J. Fish. 2(2):201-203.

Dewan, S., Ali, M. \& Islam, M.A.1977.Study on the size \& pattern of feeding of fries \& fingerlings of three major carps, eg. Labeo rohita (Ham), Catla catla \& Cirrhina mrigala. Bangladesh J. Agri. 2(2):223228.

Huq, A., Choudhury, M.A.R., Islam, M.S., Montilla,R. \& Colwell, R.R. 1996. A simple filtration method to remove plankton-associated Vibrio cholerae in raw water supplies in developing countries. Appl. Environ. Microbiol. 62(7):2508-2512.

Mellanby, H. 1975. Animal Life in Freshwater. $6^{\text {th }}$ ed. Trowbridge \& Esher, Fedowood, Burn Ltd. pp. 308.

Tonapai, G.T. 1960. Freshwater Animal in India (An Ecological Approach). Oxford \& IBH Publishing Co., New Delhi. p. 341.

Ward, H.B. \& Whipple, C.C.1959. Freshwater Biology. $2^{\text {nd }}$ ed. John Willy \& Sons Inc., New York, London, $1248 \mathrm{pp}$.

Welch, P.S. 1948. Limnological Methods. McGraw- Hill Book Co. Inc., New York. p. 381. 